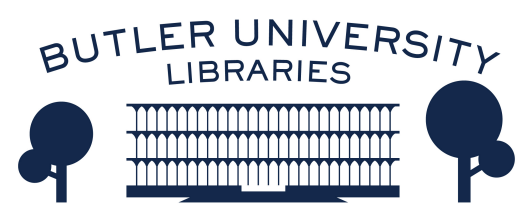

Journal of Hindu-Christian Studies

Volume 1

Article 5

January 1988

\title{
Book Review: "Risking Christ for Christ's Sake"
}

David C. Scott

Follow this and additional works at: https://digitalcommons.butler.edu/jhcs

Part of the Religion Commons

\section{Recommended Citation}

Scott, David C. (1988) "Book Review: "Risking Christ for Christ's Sake"," Journal of Hindu-Christian Studies: Vol. 1, Article 5.

Available at: https://doi.org/10.7825/2164-6279.1005

The Journal of Hindu-Christian Studies is a publication of the Society for Hindu-Christian Studies. The digital version is made available by Digital Commons @ Butler University. For questions about the Journal or the Society, please contact cbauman@butler.edu. For more information about Digital Commons @ Butler University, please contact digitalscholarship@butler.edu. 
Hindu.

Nevertheless, the book is a provocative attempt to come to grips with themes that apply to both Christianity and Hinduism. Professor Klostermaier is clearly correct in his repeated assertion that Indian theology, to be meaningful for Hindus must take its cue from themes and concerns that are central to Hinduism. Monasticism, for example, to be meaningful must relate to the samnyasa ideal. Or, Kristavidya must be related to the nation of Brahmavidya. Through such assertions the author attempts to move dialogue beyond the usual simplistic surface comparisons.

Ronald Neufeldt, Head

Department of Religious Studies

University of Calgary

Calgary, Alberta, Canada

M.M. Thomas, Risking Christ for Christ's Sake: Towards an Ecumenical Theology of Pluralism. Geneva: WCC Publications, 1987, pp. vii +122 . Reduced price in India Rs.40.

The recent explosion of studies on the issue of Christianity and religious pluralism may perhaps be signaling a kairos, a new context in which a revision of how Christian faith understands itself and other religions of faith or of no faith is both possible and necessary. M.M. Thomas' latest book is intended as a contribution to the continuing enquiry into a Christian theology of pluralism. Being something of a personal reflection of the author's one is not surprised to discover that the study has two loci-the ecumenical movement and India.

For an initial analysis of 'the challenge of pluralism' we are invited to begin with a "phenomenological survey of religion, religious pluralism and the history of interreligious relations in modern history." Arguing that this is basic for any theological reflection, Thomas heads into the wasteland of what is by now a rather hackneyed bipolar typology of religions, variously described in terms of 'monistic' and 'monotheistic', 'mystic' and 'prophetic', 'ontocratic' and 'theocratic', 'interiority' and 'confrontation', or what he himself has elsewhere termed 'unitive' and 'messianic'. A major problem with this typology is that it tends to confuse two aspects of religious experience, namely the mode and the content of the experience, or in phenomenological terms, its noetic and noematic aspects. In the type variously termed 'prophetic', 'theocratic' or 'confrontation' the two aspects usually coincided, but this is not necessarily the case with interior modes of religious experience. For example, it is hardly conceivable that Moses or Muhammad would have experienced the divine encountered in their respective moments of revelation as being ultimately identical with their innermost selves. In other words, the confrontational mode of encounter coincided with the confrontational - that is utterly transcendent-content of that which was encountered. However, there are interior or mystical modes of religious experience which, nevertheless, maintain or even reinforce the polarity between the divine and the human. If we take Friedrich Heiler's prototypical case of Martin Luther, for example, one may certainly agree that Luther represents a 'prophetic' piety, sharply antithetical to Teresa's mysticism; yet Luther's religious experience centered from the beginning on conscience, an interior phenomenon par excellence. Wherever typologies are made, it is certainly not in heaven. Indeed, typologies are intellectual constructs, usually of partial and temporary usefulness, and perhaps their major usefulness is manifested in the process by which they are demolished. The classical statement of this fact may be found in Max Seber's theory of 'ideal types'. It pertains to any application of intellectual constructs to the fluid and intrinsically anarchic reality of human experience. Certainly that part of human experience commonly designated as religion is no exception. One finds it difficult to suppose that Thomas does not know this, but unfortunately his present analysis of the challenge of pluralism is flawed by a lack of indication that he does.

The remainder of the work is a rather sketchy survey of various Christian - both Protestant and Roman Catholic-approaches to pluralism. In this, despite the somewhat provocative title of the book, the major concern, by the author's own submission, is not with "bold, pioneering adventures, risks beyond the confines of present ecclesiastical and theological structures". Rather, Thomas directs his attention to efforts within the ecumenical movement to "deepen the traditional understanding of Christ and fellowship-in-Christ in a more inclusive way." To describe and elaborate these efforts Raimundo Panikkar and Paul Devanandan are taken as representing two significant streams of Indian Christian theology in dialogue with both India's pluralistic consciousness and their own Roman Catholic and Protestant traditions.

Regrettably the discussion of Panikkar's struggles towards an 'ecumenical ecumenism' is little more than a rehash of his theology of religious pluralism. Here is but one more attempt to delineate the central thrust of Panikkar's theandric perspective on Trinitarian and Christological formulations emerging in Christianity's interface with other religious traditions. The context is the oft described developments in Roman Catholic thought. Well-known names are here-Karl Rahner, Hans Kung, Heinz Robert Schlette, Aloysius Pieris, Abhishiktananda et al. Familiar Vatican documents are marshalled. The reader is reminded of the centrality for Panikkar of the category of 'growth', a dynamic convergence of religions made possible through 'mutual fecundation' in the larger Christ of God. Predictably Panikkar is criticised for making the 'Cosmic Christ' his starting point for interfaith dialogue because it is seen by the more orthodox as weakening, if not eliminating, the historical dimension of the Christ-event. At issue, of course, is the biblical perspective on myth and history. To participate in this debate one is pleasantly surprised to find the historian of religion, Mircea Eliade being summoned. (It is seldom that theologians pay heed to historians of religion, when in fact there is much to be gained by an attentive ear.) Eliade's perspective on the relationship of historical time to mythical time raises the question as to whether the perception of the centrality of historicity may be, in part, the result of a certain misreading of the biblical material. With his usual perspicacity Thomas suggests that the matter of the relation between the historical and the mythical urgently needs to be pursued further. This, interestingly enough, bears on the matter of religious typologies referred to earlier.

The very real significance of the 
present study is the introduction of Paul Devanandan into its survey of Protestant approaches to religious pluralism. Again, the basic context is one which has been described often-the Tambaram debate and its aftermath, whose influence continues into the present. However, to Thomas' credit, other elements from the Protestant tradition are noted, especially the dominance of secularism and its manifestation in the tradition in the thought of Dietrich Bonhoeffer and Arend van Leeuwen. At least in part as a reaction to the confrontational oppositions of Christianity to other religions (Barth/Kraemer) and of secular Christianity to all religion (van Leeuwen) there emerged another approach primarily among the churches and interchurch councils of Asia. This was a theology of Christian partnership with other religions and secular ideologies involved in the struggle for new life for people. The contribution of Stanley Samartha to this emergent theology is rightly noted, as is that of C.S. Song, and the various deliberations related to the work of the East Asia Christian Conference.

The concluding portion of the book considers the contribution of Paul Devanandan to the continuing 'common quest for a new humanism'. Certainly, as Thomas argues, the significance of Devanandan for Christian ecumenism is in his insistence on and stimulation of interfaith dialogue as an ongoing concern of the church in the common search for human community. Basically, Devanandan is convinced that in the new awareness of 'person,' 'history,' and 'community' all faith comes into a common circle of theologicalanthropological concern and into the orbit of the process of a common human history. This requires an acknowledgement of "our common humanity" as well as "a secular framework" within which people of all religious traditions and of no religion can struggle together to enrich the common life of the human race. These confront all people with the twin tasks of "redemming all religions from the other-worldly preoccupation of pietism on the one hand and self-centered introversion or communalism on the other". In all of this Devanandan challenges every faith to clarify its perspective on the common humanity, the secularity which expresses it, and the place and function of religion and religions in the process of building human community. To this dialogue the Christian faith brings the gospel of the common life, of the possibility of deliverance from bondage to forms of evil that are of human creation. In the creation of this common contemporary history, the gospel of the New Humanity in Jesus, the Christ plays an essential role. Hence, all faiths, including Christianity, are compelled to open themselves-or close themselves more firmly - to one another and to Jesus, the Christ in a new way.

Basically, both Panikkar and Devanandan urge us beyond the opposition of Christianity to other religions and ideologies to recognize Christian faith as the sign of the kingdom and the fermenting leaven in the universe of faith, bringing to all humanity the transforming knowledge of the universal presence of the Christ, the mediator of human and cosmic salvation. In this process both men outline major features not only of the Christ who is more than the Jesus of Nazareth, but also of a people of Christ in world history which is more than the historical community of those who openly acknowledge Jesus as God and Saviour. True, Panikkar's "unknown Christ" of traditional faiths and Devanandan's "acknowledged Christ" of renascent faiths may have to be redefined, but both indicate a reality which demands a new understanding of the church of Jesus, the Christ in relation to a wider people of Christ.

If, as Thomas concludes, the New Humanity in Christ is to transcend Christianity, other religions, and atheistic ideologies, it must transform them all from within. Then this New Humanity will be able to take new and diverse forms in them all. Thus, the truly ecumenical ecumenism, which is really unity in the Christ has to be understood as resulting from inner reform and must accommodate diversity. Perhaps this is what it means to risk Christ for Christ's sake.

David C. Scott

The United Theological College

Bangalore, India

\section{Recent Publications}

\section{BOOKS}

Helen Ralston, Christian Ashrams: $A$ New Religious Movement in Contemporary India. Lewiston NY and Queenston, Ontario: The Edwin Mellen Press, 1987. This book focuses on the emergence and development of Christian ashrams as a religious movement which seeks to amalgamate traditional Hinduism and traditional Christianity in contemporary Indian Society. The study is based on visits to twenty Hindu ashrams and thirty-one Christian ashrams in India.

Modern Indian Responses to Religious Pluralism, edited by Harold Coward. Albany NY: State University of New York Press, 1987, 340pp, \$14.95 pb., $\$ 44.50$ hc. This book studies the way in which religions living in India have responded to the encounter with one another. Part I examines various responses from within Hinduism. Part II analyzes the responses from other religions in India, including Christianity.

\section{ARTICLES}

Helen Ralston, "Models of 'Church': A Cross-cultural Perspective." Journal of Comparative Sociology and Religion, 12, 1985, 9-37.

Helen Ralston, "Ashrams, Christian Indians and Nationalism." Canadian Review of Studies in Nationalism, 15, 2, 1988.

\section{VIEWPOINTS}

\section{Dialogue in India}

If publications and dialogue meetings are of any indication, then the dialogue initiative has come to stay in India. During the last two decades this initiative has grown among Hindus and Christians, though it is difficult to give the exact percentage of Indians who are affected by the dialogue movement. In the name of dialogue various centres are opened by the Christian communities and well-informed Hindus participating in inter-religious seminars and prayer meetings are in the increase. They find that more of 'ivingtogether' for a few days rather than formal 